\title{
PEMBUATAN TEMPAT CUCI TANGAN SEBAGAI UPAYA PENCEGAHAN COVID-19 DI DESA POLOHUNGO
}

\author{
Wahyuni Hafid ${ }^{1,}$ Marselia Sandalayuk ${ }^{2,}$ Nirmala Ismail $^{3}$
}

\author{
Universitas Gorontalo, Indonesia ${ }^{1}$ \\ email:wahyunihafid292@gmail.com \\ Universitas Gorontalo, Indonesia \\ email:marseliasandalayuk16@gmail.com \\ Universitas Gorontalo, Indonesia \\ email: nirmalaismailo4@gmail.com
}

\begin{abstract}
Abstrak
Saat ini khususnya pada akhir tahun 2019 dunia digemparkan oleh kasus yang mirip dengan penyakit Pneumonia yang terjadi di Wuhan, China. Bahkan saat ini menjadi isu kesehatan yang sangat menghebohkan di seluruh dunia, termasuk Indonesia. Penanggulang ekstrem seperti isolasi suatu daerah (lockdown) dilakukan sebagai upaya untuk meminimalisir penyebaran penyakit tersebut. Dalam hal ini mencuci tangan menggunakan air mengalir dan sabun merupakan salah satu upaya mencegah penularan virus Covid-19. Kandungan sabun terbukti secara klinis mampu membunuh bakteri, virus, dan kuman penyebab penyakit. Mencuci tangan merupakan anjuran WHO sebagai langkah dasar yang paling mudah dan aman untuk melindungi diri dari infeksi virus Covid-19. Berdasarkan pendataan di Desa Polohungo dari 196 KK (100\%) yang dijadikan responden, terdapat $191 \mathrm{KK}(97,5 \%)$ tidak memiliki tempat cuci tangan, $4 \mathrm{KK}(2,0 \%)$ memiliki tempat cuci tangan namun tidak memiliki sabun, dan $1 \mathrm{KK}$ $(0,5 \%)$ memiliki tempat cuci tangan dan memiliki sabun. Tujuan dari pengabdian ini adalah memberikan contoh pembuatan dan pemanfaatan tempat cuci tangan yang baik dan benar sebagai upaya pencegahan Covid-19. Metode yang digunakan berupa intervensi fisik yaitu pembuatan tempat cuci tangan percontohan dengan harapan dapat meningkatkan ketersediaan dan pemanfaatan tempat cuci tangan di setiap rumah yang ada di Desa Polohungo. Pada kegiatan pengabdian ini kami berhasil menyelesaikan tiga tempat cuci tangan dilengkapi dengan sabun cuci tangan dan diletakkan di dusun 1, 2, dan 3. Rencana target luaran (output) kegiatan ini yaitu adanya peningkatan jumlah tempat cuci tangan dan timbulnya kesadaran diri masyarakat terkait pentingnya cuci tangan bagi kesehatan khususnya dalam pencegahan Covid-19.
\end{abstract}

\section{Kata Kunci: intervensi fisik, tempat cuci tangan, Covid-19}

\section{Abstract}

Currently, at the end of 2019, the world was shocked by cases similar to Pneumonia disease that occurred in Wuhan, China. It has become a very horrendous health issue throughout the world, including Indonesia. Extreme countermeasures such isolation of area (lockdown) carried out as effort to minimize the spread of the disease. In this case, washing hands using water and soap is one efforts to prevent the transmission Covid-19 virus. The content of soap is clinically proven be able to kill bacteria, viruses, and germs cause disease. Hand washing is WHO recommendation as easiest and safest basic step protect yourself from infection with Covid-19 virus. Based data collection in Polohungo Village from 196 families (100\%) used respondents, there were 191 families (97.5\%) didn't have a washbasin, 4 families (2.0\%) had a washbasin but did'nt soap, and $1 \mathrm{KK}$ (0.5\%) had a washbasin and had soap. The purpose of this service to provide examples of making and using good and correct washbasin an effort to prevent Covid-19. The method used in the form of physical intervention is the creation of a washbasin the hope increasing availability and utilization of handwashing facilities every house in Polohungo. In this service activity, we 
succeeded in completing three washbasin equipped with hand soap and placed in hamlets 1,2 , and 3. The planned output of this activity is an increase the number of washbasin and the emergence of public self-awareness regarding the importance of hand washing for health, especially in prevention Covid-19.

\section{Keywords: physical intervention, washbasin, Covid-19}

\section{PENDAHULUAN}

Pada 31 Desember 2019 muncul kasus serupa dengan penyakit pneumonia di Wuhan, China. Kasus tersebut diakibatkan oleh virus corona atau yang dikenal dengan COVID-19 (Corona Virus Disease-2019) (Herliandry, dkk, 2020). Pada tanggal 11 Maret 2020, WHO (World Health Organization) menyatakan wabah penyakit akibat virus corona/Covid-19 sebagai pandemi global. Hal ini diakibatkan kasus positif di luar China yang meningkat tiga belas kali lipat pada 114 negara dengan total kematian pada saat itu mencapai 4,291 orang (Valerisha dan Marshell, 2020).

Semakin bertambahnya kasus yang terkonfirmasi virus corona, pemerintah menghimbau kepada masyarakat untuk mematuhi protokol kesehatan dimana salah satunya yaitu mencuci tangan menggunakan sabun dan air yang mengalir. Tangan adalah salah satu anggota tubuh yang harus dijaga kebersihannya, karena tangan sering terkontaminasi kotoran maupun mikroba sehingga melalui perantara tangan mikroba akan masuk kedalam tubuh (Nakoe, 2020). Mencuci tangan pakai sabun adalah salah satu upaya pencegahan atau tindakan sanitasi, dengan membersihkan tangan dan jari jemari menggunakan air dan sabun. Tangan manusia seringkali menjadi agen yang membawa kuman dan menyebabkan patogen berpindah dari satu orang atau dari alam ke orang lain melalui kontak langsung atau tidak langsung (Mustikawati, 2017).

Perilaku mencuci tangan ini akan sangat efektif untuk memutus rantai penyebaran virus tersebut. Hal ini disebabkan virus Covid-19 selain menular melalui batuk dan bersin, juga menular melalui perantara benda di sekeliling kita yang baru saja dipegang oleh pasien yang terkena penyakit Covid-19. Jika kita memegang benda yang baru saja dipegang oleh pasien Covid-19 dan memegang mulut atau hidung, kita akan ikut tertular. Kondisi ini dapat diputus dengan cara, jangan mudah memegang benda di sekitar menggunakan tangan dan minimalisir memegang mulut dan hidung. Apabila terpaksa harus memegang benda di sekitar kita dan harus memegang mulut atau hidung, kita wajib melakukan cuci tangan dengan sabun agar virus Covid-19 mati (Saputra, dkk, 2020).

Berdasarkan survey tempat yang telah dilakukan sebelumnya ditemukan bahwa Desa Polohungo merupakan salah satu desa yang ada di kecamatan dulupi, Kabupaten Boalemo yang sebagian besar masyarakatnya tidak memiliki tempat cuci tangan. Hal ini dapat dilihat dari distribusi kepemilikan tempat cuci tangan berdasarkan jumlah di Desa Polohungo, dari 196 KK (100\%) yang dijadikan responden, terdapat 191 KK (97,5\%) tidak memiliki tempat cuci tangan, 4 KK (2,0\%) memiliki tempat cuci tangan namun tidak memiliki sabun, dan 1 KK $(0,5 \%)$ memiliki tempat cuci tangan dan memiliki sabun. 
Masyarakat sudah menyepelehkan kebiasaan mencuci tangan pakai sabun setelah mereka melakukan aktifitas baik di dalam maupun di luar rumah.

Berdasarkan permasalahan di atas, maka tujuan dari kegiatan pengabdian kepada masyarakat di Desa Polohungo, Kecamatan Dulupi, Kabupaten Boalemo adalah pembuatan tempat cuci tangan percontohan yang nantinya akan dicontoh dan dimanfaatkan oleh masyarakat dalam upaya pencegahan infeksi Covid-19.

\section{METODE}

Kegiatan pengabdian kepada masyarakat berlokasi di Desa Polohungo, Kecamatan Dulupi, Kabupaten Boalemo. Kegiatan pengabdian masyarakat ini dilaksanakan pada bulan September 2021 melalui beberapa tahap yakni mulai dari perencanaan sampai dengan pelaksanaan. Adapun Rincian tahapan pengabdian masyarakat sebagai berikut:

1. Tahap awal meliputi survey dan pendataan diantaranya ketersediaan tempat cuci tangan disetiap rumah guna meminimalisir penyebaran virus Covid-19.

2. Proses perencanaan meliputi identifikasi kebutuhan, identifikasi potensi dan kelemahan yang ada, menentukan jalan keluar dan kegiatan apa yang akan dilakukan, serta membuat pengorganisasian kegiatan. Perencanaan disusun oleh tim pengabdian, pemerintah desa dan karang taruna Desa Polohungo.

3. Koordinasi dilakukan antara dosen, mahasiswa, pemerintah Desa Polohungo dan karang taruna untuk pelaksanaan kegiatan ini. Setelah disepakati dan dikoordinasikan rancangan kegiatan yang akan diajukan maka diperoleh kesepakatan waktu untuk pelaksanaan rangkaian program tersebut.

4. Kegiatan intervensi fisik berupa pembuatan tempat cuci tangan percontohan dilaksanakan pada hari sabtu 12 september 2021. Pelaksanaannya dimulai dari jam 10:30 sampai dengan 17:00 yang diawali dengan mencuci gelong bekas menggunakan sabun kemudian tahap selanjutnya yaitu mengecat gelong dengan cat yang berwarna ungu dan kuning hingga cat tersebut kering. Setelah itu gelong tersebut di isi air dan juga disediakan sabun, setelah semuanya sudah siap selanjutnya tempat cuci tangan dan juga sabun kami letakan di dusun satu, dua, dan tiga. Dalam hal ini kami di bantu oleh pemdes, masyarakat dan juga karang taruna Desa Polohungo.

\section{HASIL DAN PEMBAHASAN}

Bentuk partisipasi masyarakat dalam pelaksanaan kegiatan ini cukup aktif dan menyambut baik kegiatan yang dilakukan. Bentuk partisipasi tersebut terwujud dalam kesediaan menyediakan beberapa perlengkapan yang dibutuhkan berupa gelong bekas, kayu, paku, botol-botol sabun, dll. Kegiatan pengabdian kepada masyarakat yang dilaksanakan dengan bentuk intervensi fisik berupa pembuatan tempat cuci tangan percontohan melibatkan dosen, mahasiswa peserta PBL 2, remaja karang taruna dan beberapa masyarakat Desa Polohungo. 


\section{Pembuatan Tempat Cuci Tangan Percontohan}

Kegiatan intervensi fisik berupa pembuatan tempat cuci tangan percontohan dilakukan guna meningkatkan ketersediaan dan pemanfaatan tempat cuci tangan yang baik dan benar pada setiap rumah yang ada di Desa polohungo. Selain itu juga dapat memberikan kesadaran tentang pentingnya mencuci tangan menggunakan sabun dan air mengalir sebelum dan setelah melakukan aktifitas baik di dalam maupun diluar rumah sebagai upaya pencegahan infeksi virus Covid-19.

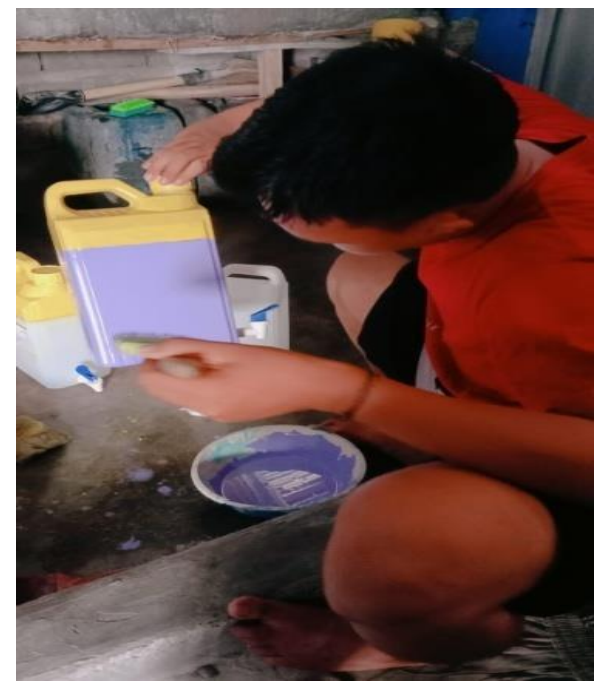

\section{Gambar 1. Mengecat Gelong Bekas yang Sudah Bersih}

Proses pengecatan gelong bekas menggunakan cat yang dicampur dengan bensin kami lakukan disalah satu rumah warga yang membantu kami dalam membuat tempat cuci tangan.

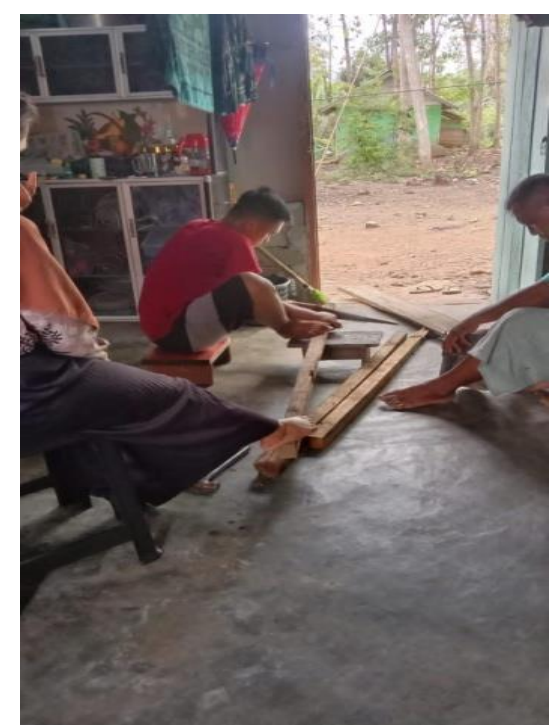

Gambar 2. Memotong Kayu sebagai Tempat Meletakkan Tempat Cuci Tangan

Dalam proses pembuatan tempat cuci tangan kami dibantu oleh masyarakat sekitar dari mencari gelong bekas, kayu bekas yang masi bisa digunakan kembali. Tidak hanya 
E-ISSN: 2776-3331

Vol. 1, No. 2, pp. 136-141

November, 2021

itu bahkan masyarakat tersebut membantu kami sampai tempat cuci tangan tersebut selesai.

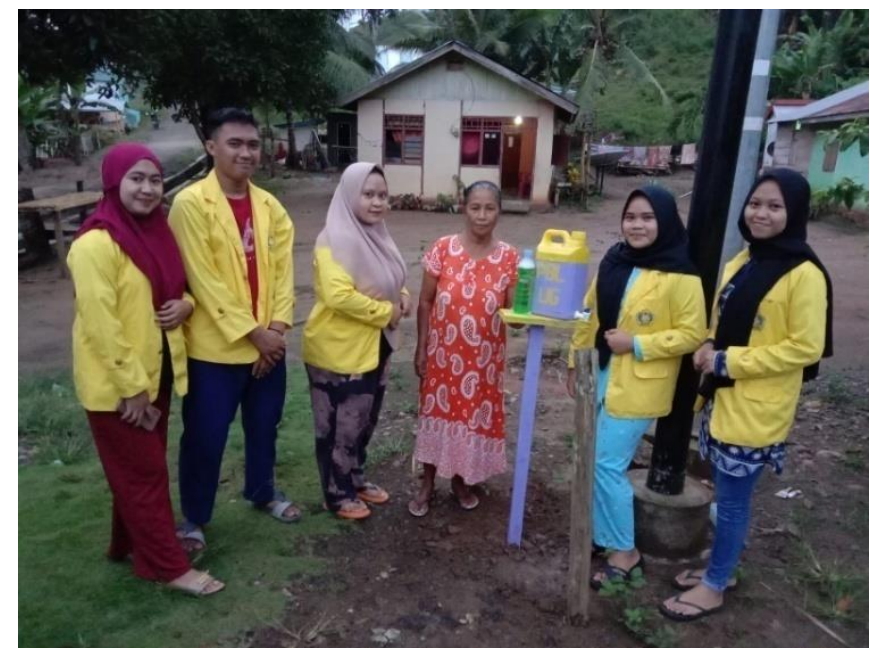

Gambar 3. Meletakan Tempat Cuci Tangan

Pada tahap akhir setelah tempat cuci tangan selesai dibuat kemudian kami meletakan tempat cuci tangan dan sabun tersebut di depan rumah warga desa Polohungo tepatnya pada dusun 1, 2, dan 3 dengan tujuan sebagai contoh agar masyarakat membuat dan memanfaatkan tempat cuci tangan tersebut secara maksimal serta dapat memutus rantai penyebaran Covid-19.

Selain kegiatan pembuatan tempat cuci tangan percontohan, kami juga melakukan penyuluhan tentang cara mencuci tangan yang baik dan benar. Dengan adanya tempat cuci tangan ini diharapkan masyarakat menjadi lebih memperhatikan kebersihan dengan cara mencuci tangan menggunakan sabun dan air mengalir terutama setelah selesai melakukan aktivitas baik di dalam rumah maupun di luar rumah. Selain itu, melalui program ini diharapkan masyarakat dapat membuat tempat cuci tangan sendiri dimasing-masing rumah. Program ini disambut baik oleh perangkat desa serta masyarakat sekitar, bentuk tindak lanjut dari program ini diharapkan adanya kerjasama antara perangkat desa dan masyarakat dalam rangka menumbuhkan semangat hidup bersih dan sehat. Hidup bersih dan sehat juga merupakan perilaku kesehatan yang dilakukan atas kesadaran seseorang sehingga dapat menangani dirinya sendiri dalam hal kesehatan serta dapat berperan aktif dalam kegiatan-kegiatan kesehatan baik bagi inidividu masing-masing maupun orang lain, salah satu upaya hidup bersih dan sehat dapat dilakukan dengan rajin mencuci tangan setelah melakukan aktivitas (Tentama, 2017).

\section{KESIMPULAN}

Pelaksanaan pengabdian kepada masyarakat dengan melakukan pembuatan tempat cuci tangan percontohan dan penyuluhan mencuci tangan pakai sabun dan air mengalir dengan baik dan benar di Desa Polohungo menjadi satu hal yang penting dilakukan untuk pencegahan infeksi virus Covid-19. Pembuatan tempat cuci tangan 
E-ISSN: 2776-3331

Vol. 1, No. 2, pp. 136-141

November, 2021

percontohan juga bertujuan agar masyarakat bisa memanfaatkan kembali tempat cuci tangan tersebut bahkan mampu membuat tempat cuci tangan sendiri dimasing-masing rumah dan juga menumbuhkan kesadaran diri masyarakat tentang pentingnya menerapkan pola hidup bersih dan sehat.

\section{REFERENSI}

Herliandry, dkk.(2020). Pembelajaran pada masa pandemic covid-19.Jurnal Teknologi Pendidikan, 22 (1), 65-70

Mustikawati, Intan Silviana. (2017). Perilaku cuci tangan pakai sabun: studi kualitatif pada ibu-ibu di kampong nelayan muara angke Jakarta Utara. ARKESMAS, 2 (1), 115-125

Nakoe, dkk. (2020). Perbedaan efektivitas hand-sanitizer dengan cuci tangan menggunakan sabun sebagai bentuk pencegahan covid-19. Jambura Journal of Health Sciences and Research, 2 (2), 65-70

Saputra, dkk. (2020). Penerapan wastafelportable sebagai upaya pencegahan covid-19 di kantor Kelurahan Gedongan Kecamatan Colomadu. Jurnal Pengabdian Kepada Masyarakat MEDITEG, 5 (1), 44-49

Tentama, Fatwa. (2017). Penerapan perilaku hidup bersih dan sehat (PHBS) demi kesejahteraan masyarakat Kecamatan Tuntang Kabupaten Semarang Jawa Tengah. Jurnal Pemberdayaan, 1 (1), 13-18.

Valerisha, Anggia dan Marshell Adi Putra. (2020). Pandemi global covid-19 dan problenatika Negara-bangsa: transparansi data sebagai vaksin socio-digital. Jurnal Ilmiah Hubungan Internasional.

http://journal.unpar.ac.id/index.php/JurnalIlmiahHubunganInternasiona/article/ view/3871/2913 